CIRR XXI (72) 2015, 167-197

ISSN 1848-5782

UDC 65:338.2:339.96

DOI 10.1515/cirr-2015-0006

\title{
Project Management in Development Aid Industry - Public vs. Private
}

Dragana Simović

\section{Abstract}

This article examines the relationship between the type of a development aid implementing organisation (public or private) and the quality of project management in development aid. The author begins with main public administration considerations - how public aid administration is different from private and furthermore, how particular sectoral characteristics of organisations influence the quality of the management process. The article combines empirical findings on the differences between the public and private sector with a complex setting of development aid and main success factors in development aid activity, in order to determine whether for-profit or public companies are more likely to achieve better project management processes. The article identifies some indices that favorise private companies, and outlines further necessary steps that should be taken in order to broaden the argumentation and confirm or reject this assertion.

\section{KEY WORDS:}

development aid, public-private differences, project management quality, aid effectiveness 


\section{Introduction}

Whether project management practices within private companies that implement foreign aid projects are better than within public agencies is an important question with far reaching policy implications. Public-private differences have been one of the central topics of the public administration field, but development management studies are lacking attempts to apply these findings. Attempts to measure aid quality and assess aid management practices within official aid agencies have focused on the agency-level, while project practices within implementing organisations in the field have usually been completely excluded, although the role of implementing organisations can be pivotal in determining short- and longterm impacts of aid (Andersson \& Aver 2005). In the light of the Millennium Development Goals (MDG) deadline, this research is motivated by the wish to formulate policy implications for better and more sustainable aid.

Official development cooperation agencies started contracting out entire projects or parts of their projects in the 1980s. The first contracts were made with universities and research institutions, and later on forprofit companies were contracted to implement development aid projects. This change was influenced by a global privatisation movement in which governments started outsourcing traditional domestic services. The goal of contracting out was to create a more efficient and effective delivery of services through a system that provides better management than public management (Hart 1983). There has been ample research focused on private-public differences and effects of contracting out of traditionally governmental services, such as health care, transportation and education. However, the phenomenon of contracting out, even though overwhelmingly present in the field of development aid, has most definitely escaped scholarly attention (Huysentruyt 2011), as there has hardly been any scholarly research examining the consequences of contracting out upon aid efficiency, effectiveness or quality, after the inclusion of the private sector as a common player in the field. Some scholarly research on contracting out has been conducted (see Huysentruyt 2011 and Berrios 2000), but with a special focus on only two development agencies, the USAID and the DFID. Other research conducted in the field of development aid has rarely analysed in depth 
the sectoral belonging of the organisations implementing aid as a factor which plays a decisive role.

One reason why this may be the case is that it was rather late that the behaviour of donors was connected with results in the development aid industry. It was mostly recipient countries that were scrutinized. One of the major studies which had far reaching policy consequences (Burnside \& Dollar 2000) stated that aid had better impact on growth in recipient countries with good fiscal, trade and monetary policies. High corruption levels and the ignorance of autocratic leaders were considered to diminish aid effectiveness (Knutsen 2009; Meredith 2006; Ayittey 2005; Baland et al. 2010). Some further empirical studies have even shown that aid can have detrimental effects on citizens' welfare in countries with autocratic regimes (Easterly 2003; van de Walle 2001). This scholarly research laid out the basis for a policy of conditioning, which is common within many donor countries. In return for foreign aid, donor countries demand macroeconomic stability, non-interference with market pricing, openness to international trade and privatization of state-owned industries (Easterly 2003). In that way donors secure that their money is not wasted because of inadequate in-country policies.

On the other hand, research concerned with development aid has dealt with the behaviour of donors and implementing bodies to a much lesser extent. The first analytic research which grappled with the actual practices of different donors-those over which donor organisations have control that are likely to affect the long-run effectiveness of aid were conducted by Mosley (1985) and White and Woestman (1994). They strictly focused on donor policies (the amount of aid given; the terms and conditions under which it is given; the extent to which it is tied; its allocation to recipients) as determinants of aid quality. Deininger et al. (1998) and Kilby (2000) studied World Bank projects and convincingly demonstrated that donor efforts can improve aid effectiveness. Later on, Wane's empirical research (2004) dealing with the determinants of foreign aid quality confirmed the results of Burnside and Dollar (2000) that aid works in countries with good governance and reasonable economic policies, but also proved that aid is not donor-neutral and that its effectiveness is not exclusively determined by the characteristics of the recipients. Following a similar research direction Tierney et al. (2011) proved that the nature of the organisation implementing 
aid can also influence aid effectiveness. The latest research focusing on specific policies of donor agencies assumed to have a powerful impact on aid outcomes have been done by Easterly and Williamson (Easterly \& Williamson 2011), Easterly and Pfutze (2008) and the Kharas (2011) Quality of Official Development Assistance Index (QUODA).

This research has shown that there is a strong connection between donor behaviour and aid outcomes. Under the behaviour of donors that can influence aid outcomes come aid quantity, the geographical distribution of aid, the type of aid (budget support, project/programme-aid), the level to which aid is tied, transparency, aid fragmentation, the conditioning policy etc. These are just some of the choices that policy-makers in donor countries face and that might, to a higher or lower extent, influence aid outcomes. The choice whether to contract a service delivery or to use a governmental agency to implement an aid project is one of the policy options which has caused attention of researchers in other industries. Without disputing previous research that stipulated that donor policies such as aid allocation or aid fragmentation influence aid outcomes, the author wishes to emphasize the importance of the role of implementing organisations for the entire aid delivery process.

Development aid projects which are implemented by a tender-winning for-profit company and projects which are delivered by a governmental official aid agency are likely to be different. Without assuming qualitative implications, one could speculate that project staff is likely to operate differently in the field and have different incentives - their reporting process could show variations, their learning efforts and abilities might be different and the way they communicate and connect to the main project stakeholders and beneficiaries could also vary. All of these constitute important elements of project management and could influence its quality, which has impact on overall aid effectiveness. That is why it would be important to deeply investigate these two types of aid implementation and their implications on the project management processes.

As briefly mentioned above, another novelty in the approach that this research brings is project-level research. The idea behind project-level research is favoured in the works of Miller (2011), which claims that macro-level studies do not have real practical value and that project- 
and program-level analysis tends to be more reliable. The author is of the opinion that although the policies on the agency-level do influence the quality of aid, the decisive role is played by actors in the field. Whether a well-designed development aid project turns out to be a success or a failure is to a great extent a matter of the work being done by the project staff in the field. Therefore, the author argues, applying the core approach to public-private difference, that is whether an organisation implementing aid is private or public is an important determinant in quality of management within this organisation (O'Toole \& Meier 2003; 2004).

The article begins with a brief historical description of the development aid field in order to describe the setting. It is followed by an overview of the changes that occurred in the entire public administration sector due to the introduction of New Public Management (NPM), with a special emphasis on changes within the institutions managing and implementing development aid.

The second part investigates the possibilities of application of project management knowledge in the development aid industry and outlines specific features of this industry in comparison to other, traditional fields of project management knowledge application. The author reviews the existing related literature and identifies main project management practices that apparently bring better aid outcomes. These project management dimensions serve to determine the type of organisation/ management that is more likely to satisfy the special criteria of successful project management in development aid settings.

The third part presents the existing debate about the differences between public and private organisations and public and private management. These findings will be used to build up the argumentation on why sector may play a very important role when it comes to development aid delivery at the project level, and try to answer the main question: which sector actually does a better job in this field? The approach used in this article will mostly be a theoretical one, and its assumptions remain to be confirmed through a field study at a later stage of research.

The article concludes with a discussion of the findings and further steps which are necessary to make in order to reach plausible assertions. 


\section{The Development Aid Field}

Development aid, in the narrow sense of the word, was first introduced in the aftermath of the Second World War with the Marshall Plan. In that period states had a multitude of tasks at their hands, from creating conditions for economic prosperity to correcting leadership in those areas where the private sector appeared ineffective (Dwivedi 2002). However, already in the 1970s the dissatisfaction with big Weberian hierarchical public administrations grew: they were often described as old-fashioned and dysfunctional (Kapucu 2007). At the same time, a strong belief in the market and in the idea that private is better than public lead to widespread and deep changes in public administrations world-wide. This entire movement is known as New Public Management. The term NPM has been defined in many different ways (Greener 2013), and although it has never been a very consistent set of ideas (Manning 2002), there is a general agreement that it entails the following elements: the professionalisation of management in the public sector, performance measuring, emphasis on outputs instead of inputs, the disaggregation of units in the public sector in order to make them easier to manage, a shift to greater competition, inclusion of private sector styles of management practice and an accent on greater discipline and resource use (Hood 1991).

NPM has contributed to a wide-spread use of various managerial tools initially created for the private sector, as the underlying idea of NPM was that "management is management" (Murray 1975), and that public organisations should import behaviour models and managerial processes from the private sector (Box 1999; Carroll \& Garkut 1996; Hood 1991). As contracting out meant employing private companies for service delivery, it was seen as one of the ways to improve service provision, cut costs and reduce the role of government. Those services that have traditionally been in the hands of states started being contracted out, e.g. health care, education and even police protection in some countries.

In development aid, dissatisfaction with achieved results coincided with discontent with big governments and similar changes were introduced in those parts of governmental agencies in charge of development aid. As a response to economic, social and political pressures, governments 
started contracting out services in development aid to for-profit and non-governmental organisations (NGOS). Findings from the United States reported that the USAID was viewed as being extremely badly managed and incompetent, leading to even suggestions to close it (Berrios 2000). In Sweden a report on governmental roles and responsibilities concluded that foreign assistance could be performed more cost-effectively if it were contracted to private actors through a competitive bidding process (Sida 1989). Similar reasoning was used in other countries as well, so nowadays both multilateral organisations and a majority of governments routinely use private (for-profit or non-profit) entities for project delivery. At the same time, there are countries that have not gone that far with implementation of the NPM ideas and therefore privatisation and outsourcing have not taken place in the development aid field. Instead, they keep using their own offices and project staff for foreign aid project delivery in developing countries. This research explores the consequences of these two policies with a focus on management quality on the level of individual aid projects.

Despite early assessments of NPM that have been overly optimistic, such as the one that we are lucky to be living at the time when truth has been discovered (Osborne \& Gaebler 1992), later estimates of the actual overall effects of NPM policies are rather ambiguous. Big claims were made by NPM supporters, both concerning the improvement of government performance and about cost savings (Manning 2002), but direct comparison of before and after, concerning both quality and costs are hard to make (for a discussion, see Domberger \& Jensen 1997). Concerning the costs, findings are very different and range between $10 \%$ and $50 \%$, depending on the country and industry (Domberger \& Jensen 1997), but transaction costs can be large enough to offset these savings. As far as quality is concerned, similar findings both in favour and against contracting out can be found, and research of this type is extremely burdened by the concept of quality of services which is hard to measure and rarely allows for direct before-after comparisons.

Acknowledging these difficulties, this research focuses on the differences in management practices within private and public implementing organisations, which are likely to influence the quality of aid, instead of trying to assess the direct effects of contracting out on aid quality, as it would have been at least equally problematic as in other fields. 


\section{Project Management in Development Aid}

The central question of project management research since the late 1960s, regardless of the field in which the findings could be applied, attempted to answer the following question: What factors contribute to the success of a project? In addition to that, how can we know if a certain project is successful; namely, what criteria can we use to measure project success? Although the development aid industry is dominated by project-type interventions, it benefited from project management knowledge rather late. Some of the research from the late 1990s argued that, despite the difference between international development projects and "hard-type" projects, the solution to the most common problems in development aid is to learn the basics of project management and apply them in this specific context (Youker 1999). This traditional view has been challenged by some more recent research calling for more industryspecific issues and challenges (Carden \& Egan 2008), which has led to some initial findings about industry-specific factors contributing to project success in the development aid industry.

Another debate in management literature which is of importance for this research is whether management practices can be evaluated as good or bad, or whether every management practice is contingent (Woodward 1958). Supporting findings from Bloom et al. (2011), the author starts from the assumption that there is a basic set of management practices which contribute to better outcomes. The goal for now is to identify these practices (dimensions) while in the later phase of research they will be elaborated and specific measurable indicators for each dimension will be created. This will enable the assessment (from good to bad), the measurement, and comparison of project management practices in development aid.

Finally, of the highest importance for this entire research-project is the general belief that management matters for overall performance and project effectiveness. The various reports found (O'Toole \& Meier 2003; Nicholson-Crotty \& O'Toole 2004; O'Toole \& Meier 2004) that although it is not the only determinant of performance, it is a very substantial one. This means that, if we are able to operationalise management practices in 
a way that they could be measured, it gives us a possibility to compare these practices in different projects while they are in their implementation phase and see which type of project delivery achieves a higher quality of management on average. Based on that we can assume which projects are more likely to perform better and deliver more effective aid.

In these efforts, it must be acknowledged that the development aid field differs from other traditional fields of applying project management knowledge. A short review of the literature outlining the uniqueness of the international development field compared with traditional projects reveals the following:

1. Project goals: Project goals in development aid are usually connected to social transformation and human development which makes project performance measurement notionally complex (Crawford \& Bryce 2003);

2. Strong political component: development aid projects contain a very strong political component due to specific impacts of aid interventions (Britton 1998);

3. Environment: development aid projects usually take place in an environment of diverse and even contradictory expectations which makes traditional project management approaches less appropriate, and where flexibility in decision-making plays a very significant role for project success (Blunt 1992);

4. Multiple stakeholders: international aid projects are characterised with a very complex web of many stakeholders (Khang \& Moe 2008).

Once the main characteristics of the industry have been specified, a further challenge consists of finding out which aspects or dimensions of the management process actually carry performance implications.

In order to identify those project management processes and practices that might lead to better outcomes in this specific industry, the author has started from 10 management knowledge areas as defined by $A$ guide to the Project Management Body of Knowledge (PMBOK® Guide) (Project Management Institute 2000): project integration management, 
project scope management, project time management, project cost management, project quality management, project human resource management, project communication management, project risk management, project procurement management, project stakeholders management. These areas help as a starting point, but not all these knowledge areas are of equal importance in aid industry.

Some significant empirical research concerning elements of project management that determine organisational performance and project success in development aid have already been conducted. So far we know that there is a direct correlation between project success and use of monitoring and evaluation tools (lka, Diallo \& Thuillier 2010) and that most prominent critical success factors for the World Bank projects are project design and project monitoring (Ika et al. 2012). It should be pointed out that although project design has been identified as one of the important factors contributing to project success, it will not be included in the operationalisation of project management practices as the organisations implementing the aid often do not have the official power to influence the project design. As it is outside their field of action, it would not be fair to punish/reward the organisations for something that they have absolutely no influence on.

Furthermore, in orderto operationalize the conceptof projectmanagement processes, as needed in this research, besides PMBOK knowledge areas and empirical findings on industry-specific success factors, the author has reviewed the literature determining project management success factors knowledge stemming from general management literature. Based on that, it is possible to identify four components which help the operationalisation of the term project management process, as needed for this research:

1. Information management system - is a standardized set of automated tools available within the organisation and integrated into a system used to support the need for information (PMI 2013). The most commonly used management information system in development aid is the monitoring and evaluation (M\&E) system. There is generally a wide agreement that M\&E should form an important component of any aid project, and the rhetoric concerning M\&E affirms this view, the practice of M\&E appears to oppose it (Crawford 2004). Therefore it is of great importance for the management 
of a development aid project to have a well-functioning M\&E system.

2. Stakeholder management system - project stakeholders are individuals and organisations that are actively involved in the project, or whose interests may be affected as a result of project execution or project completion. In development aid, the most important project stakeholders are final project beneficiaries. General project management literature has identified client consultation as one of ten project success factors (Pinto \& Slevin 1987) whereas in the development aid field effective consultation with stakeholders and strong local ownership of the project are identified as critical success factors. The Paris Declaration also defined ownership as one of five principles for making aid more effective (High Level Forum 2005), and there is a general consensus that development aid projects cannot be successful without strong involvement of project beneficiaries, who are also of great importance for the sustainability of development aid projects.

3. Team-leader - besides the general acceptance that knowledge, competence, personal characteristics and behaviour of a team leader form a significant success factor within any industry, industry specific research done for the development aid industry confirm his/her importance (Steinfort 2010).

4. Knowledge management system - knowledge management is the process of converting raw information into relevant knowledge and using this knowledge to achieve the aims; it is of great importance for organisational performance and organisational learning. Roche (1999) argues that it is of central importance for the international cooperation field.

The next part discusses basic characteristics of public and private organisations, as identified in public administration literature. Differences between the two sectors are described in the literature, but the author has concentrated on those that could influence the management process quality, within the development field, keeping in mind the following:

- the differences should concern only the implementation phase 
of the project, as management practices will be assessed in the implementation phase;

- they should show foreseeable impact on at least one of the four project management dimensions as defined above.

\section{Differences Between the Public and Private Sector}

The first issue when determining the differences between public and private organisations concerns the criteria that are used to define the two sectors in the first place. Researchers often avoided a clear demarcation between the public and private sector, as oversimplification could be misleading (Rainey 2009). Nonetheless, these three characteristics are widely accepted in the literature: source of financial resources, ownership, and mode of governance (Perry \& Rainey 1988) as basic criteria used to determine belonging either to the private or public sector. In reality, of course, many hybrid forms of organisations exist, so that some researchers would rather argue that there is a certain continuum between strictly forprofit firms on one side and rigidly governmental agencies on the other, with a lot of hybrid organisations between the two ideal types (Fottler 1981). However, for the purpose of this article, by using the term public organisations, the author refers to those that are publicly funded and owned, as well as controlled by rules and directives (Fottler 1981), while private organisations are those that are privately owned, and guided by market forces. It means that a for-profit consulting company, which implements projects funded by a donor government, is to be regarded as a private company, although part of its funds are actually public.

By now, three conceptual frameworks have crystallized from the longlasting debate about the differences between the public and private sector: the generic approach, the core approach and the dimensional approach (Scott \& Falcone 1998). The proponents of the generic approach argue that there are no essential differences between the two sectors, and they reject the distinctions between sectors as pure stereotypes (Lau et al. 1980; Murray 1975). The core approach advocates 
argue that the two sectors actually operate differently (Rainey 1989; Ranson \& Stewart 1989; Nutt \& Backoff 1993; Williamson 1999; Baarspul \& Wilderom 2011). Their argumentation is based either on the economic theory of property rights, suggesting that public organisations have lower efficiency (Clarkson 1972), or public choice theory claiming that public organisations are unresponsive to the preferences of people who receive their services (Boyne 1998). In the dimensional approach, developed by Bozeman (1987) publicness is seen as multidimensional, explaining that some organisations can be more political in some aspects, but more economical in others. This approach enables the analysis of some organisational forms that do not fit into the simplified dichotomy of public and private and reflects the growing number of hybrid organisations. The author will use the core approach in this article, as its emphasis on public-private differences is most consistent with research where sectoral difference is the independent variable.

Differences and similarities between the private and public sector comprise a research topic that has been the core question of public administration since its founding (Hvidman \& Andersen 2013). Many differences have been identified, many only insinuated. For the purpose of this article, three differences will be outline and further discussed: the usage of same tools with different consequences; the difference in variance of actions and levels of bureaucracy, and red tape. These three are chosen as they are likely to directly affect one or more of the four project management dimensions which are taken as having special importance in the field of development aid.

\section{Same Tools Different Outcomes}

NPM has contributed to a widespread use of various managerial tools initially created for the private sector, as the underlying idea of NPM was that "management is management" (Murray 1975), and that public organisations should import behaviour models and managerial processes from the private sector (Box 1999; Carroll \& Garkut 1996; Hood 1991). The efforts to improve public sector management during the NPM era focused to a great extent on organisational performance and results. Performance management is a generic term for different models of management (Moynihan 2008), including the results-based management (RBM) which was introduced in the institutions managing 
official development assistance. During the 1990s it was introduced in the entire United Nations (UN) System, Canadian International Development Agency (CIDA), USAID, Norwegian Agency for Development Cooperation (NORAD), Swedish International Development Cooperation Agency (Sida), and many other multilateral and bilateral state agencies. The aim of the RBM was to improve effectiveness and accountability. According to Ireland et al. (2003) and Binnedjikt (2001) the RBM also serves to improve management (i.e. learning, improved decision-making, and planning etc.) and performance reporting. The entire industry was very much oriented on how much aid was given and what activities have been undertaken, without critical assessment of what has actually been achieved. RBM was considered to be a powerful idea which could change the way how aid agencies think, focusing on outcomes instead of inputs and outputs and on impacts instead of activities (Flint 2003).

Although the generic management literature would suggest that application of managerial tools is not contingent on the sector where they are applied, recent discussion in the field of public administration offer different assumptions. Sparked by the article written by Meier and O'Toole (2011) about differences between public and private management, the debate had an intention to move the focus from the question of how public and private organisations differ, to how outcomes of managerial actions vary in these two sectors. This change of focus is important, as it may contribute to a better understanding of outcomes of RBM application in the two sectors that are being examined here.

Meier and O'Toole argued that internal organisational characteristics such as goal clarity and incentives can influence the way tools are applied, and moreover, with what outcomes. In public organisations where multiple goals and lack of incentives to focus on good performance, but rather on following rules and procedures, may indeed negatively influence the application of result-oriented tools such as RBM. On the other hand, private for-profit organisations have a clear and central profit-making orientation. In the case of project delivery in development aid, the achievement of project goals is what brings profits, as good performance is most likely awarded with future contracts. Therefore, the results-orientation is central to the survival of private companies, whereas in public agencies incentives to accomplish project results will probably not be as strong. 
Empirical findings about different outcomes within public and private companies are for now not very rich. The authors Hvidman and Andersen (2013) used the example of performance management to investigate how management principles and techniques imported from the private sector influence management outcomes in the public sector. The empirical study has shown, applied on public and private schools in Denmark, that performance management is indeed less effective when used in public organisations. It is of course clear that one cannot generalise these findings based on one example, but some assessments of RBM usage and application from our field of interest already exist.

Meier (2003) argues that the public sector, which has traditionally been focused on input and activities, does not possess the organisational ability to create a management culture based on results. That is why the attempts to introduce RBM have in most cases been assessed as problematic. Even the official assessment reports on the RBM application do not seem to be exceptionally convincing. Some reviews account for varying level of progress (Bester 2012) and inform that certain efforts were more fruitful than others (Ortiz et al. 2004) whereas Vähämäki et al. (2011) describe repeated challenges over the course of development cooperation history.

These findings have outlined existing difficulties with the application of RBM within official agencies; unfortunately there are no empirical studies which have dealt with RBM within for-profit companies implementing development aid. These partial findings do not allow for final assumptions and generalisations.

By now we may conclude that this basic management tool applied in development aid with the intention to increase effectiveness and performance of foreign aid organisations on all levels has not fulfilled its expectations. Relying additionally on empirical findings of Hvidman and Andersen (2013), that performance management tools are less effective in public organisations, we may speculate that private organisations, using the same managerial tool, would achieve better quality of project management. As research to date has been rather scarce, the claims made here cannot be final. 
At this point, it would be useful to point out that NPM and RBM, in general and also in particular in the development aid field, have been prone to severe critique, as being overly reductionist, managerialist and in contrast to the flexibility which is needed in development aid. Nonetheless, the objective of the article was not to critically engage in a discussion about the appropriateness of the RBM as a tool for the development aid industry, but to depict, on the example of RBM which has been dominantly used in development aid, how managerial practices tend to be dependent upon the industry where they are used and explain why usage of some tools by for-profit companies may be more in line with good managerial practices in development aid.

\section{Difference in Variance of Actions}

One very common assertion among scholars who examined publicprivate differences is that managers in the public sector have a rather limited variance of actions in comparison to private sector managers (Wilson 1989; Rainey 2009; Meier \& O'Toole 2011). Private organisations, theoretically, have more discretion in inducements (Baldwin 1990; Bretschneider 1990; Rainey 2009; Scott \& Falcone 1998). At the same time, Rainey (2009) argues that decisions in public organisations involve more complexity, intervention, and interruption than those in their private counterparts.

Findings from an interview-based public-private comparison (Eðvarðsson \& Sigurðardóttir 2010) go in line with the previous claims. The survey revealed that administrators of public bodies have a weaker mandate to make decisions than their colleagues in private enterprises and that it takes longer to make these decisions in public institutions than in private ones. These findings may have serious consequences for the management processes in the field of development aid.

Looking at the four dimensions of project management, these limitations in action would mostly affect the team-leader dimension, as the limitation of potential choices of action has direct consequences on the behaviour of the team-leader. The rich project management literature depicted the significant importance that a team-leader has for overall project success (Gaddis 1959; Kerzner 1998; Zimmerer \& Yasin 1998). His/her behaviors 
(Crawford 2000) form in themselves a significant factor contributing to project success, which has been confirmed in different theoretical and empirical works on critical project management success factors (Belassi \& Tukel 1996) outside and within the development aid industry.

The above considerations allow for the creation of a hypothesis concerning the quality of project management in the development aid industry - that private organisations are likely to be more suitable for project delivery in the field of development aid, in the environment where one is constantly exposed to nonstandard problems in rather unfamiliar settings. Thinking unconventionally and the possibility to act fast become crucial under such circumstances. Having greater freedom of choice while making decisions and the possibility to apply atypical solutions are utterly important success factors in this industry. Public decision-making, which is burdened by multiple bureaucratic layers and hindered by meticulous procedures, seems to be less suitable for the field of development aid.

\section{Bureaucracy and Red Tape}

One rather common claim about public organisations is that they are more bureaucratic than their private counterparts (Emmert \& Crow 1988; Holdaway et al. 1975; Lan \& Rainey 1992; Rainey 1983; Scott \& Falcone 1998), that they tend to follow more procedures, and that they are less flexible (Bozeman \& Kingsley 1998; Farnham \& Horton 1996). One side-effect of bureaucracy, as defined by Bozeman and Scott (1996), is red tape. It refers to "the constraint or impediment to an organisation's freedom as a result of laws, rules, regulations and procedures" (Baldwin 1990: 8). It is considered to be counter-productive as significantly more attention is paid to respecting existing rules and following procedures than on accomplishing results (Bozeman \& Scott 1996). In the development industry it would be directly in contrast with the results agenda and counterproductive to aid effectiveness efforts. One way to explain this strong focus on rules and procedures is through the incentive structure that exists within public organisations, where penalties occur as a consequence of the violation of existing rules (Fottler 1981). In such an environment, any behaviour which may contain creative solutions that would accomplish results but would not follow existing rules by the letter would not be carried out. The remaining question is whether public organisations indeed suffer from more bureaucracy and red tape. 
Empirical results have not been unambiguous. Although many empirical studies (Bretschneider 1990; Bozeman et al. 1992; Rainey et al. 1976) have confirmed, as expected, that public organisations indeed have more red tape, Buchanan's findings (1975), on the contrary, claim that red tape plays a more significant role in the private sector. Furthermore, Knot (1993) and Lachman (1985) claim that the role of rules in private management can be even more important than in public management. The results are equally vague when it comes to red tape research; there are no definite answers to which sector might be suffering from red tape to a higher extent.

Considering such contradictory findings on the different characteristics of the two sectors, it could be helpful to examine the particular effects that more bureaucracy and red tape (although one cannot, at this stage, claim with certainty which organisations are more affected by them), could have on organisational outcomes and performance.

Research examining the connection between overall organisational performance and red tape discovered that red tape is not bad per se (Pandey \& Moynihan 2006) as many organisations operate under similarly burdensome rules, but their performance varies a great deal. In a study conducted on the United States agencies, Pandey and Moynihan (2006) find that red tape may be mitigated through political support and organisational culture, and that some agencies have indeed managed to overcome it.

However, considering the effects of red tape without mitigating variables, and concentrating on particular management systems that may be affected by it, reveals that the human resource management system and the information system seem to be particularly affected by the existence of red tape (Pandey et al. 2007). This could have relevance on the development aid sector, as the information management system is one of the success factors of project management and it plays a significant role for the overall quality of management. It has also been empirically proven as one of the major success factors from a project coordinators' perspective (lka et al. 2010).

Easterly (2002) examined the problem of bureaucratic burden in the field of development aid and argued that bureaucracies behave best 
when there is high feedback from beneficiaries, or an incentive for the bureaucracies to respond to the given feedback. The problem of giving feedback is "particularly acute" (Easterly 2002: 244) in foreign aid where final beneficiaries of goods or services do not actually pay for goods and services themselves. In the public sector in general, citizens pay for services and they can express their dissatisfaction with public services through protests, petitions, and in elections. Feedback of this kind does not exist in the development aid field, as the main beneficiaries are in aid recipient countries and those financing the goods and services in the development aid field are actually citizens of a donor country. This phenomenon, known as a broken feedback loop, is well known and thoroughly depicted and discussed in development aid literature (Gibson et al. 2005). These findings tell us that neither high feedback from service beneficiaries, nor incentives for bureaucrats to respond to feedback could act as a mitigating factor in development aid.

These findings can help us create a hypothesis that bureaucracy and red tape, if present within implementing organisations, can have negative effects on the quality of project management processes. Yet, in order to formulate a plausible hypothesis, a rigorous assessment of the level of bureaucracy and red tape within development aid agencies vs. consulting companies contracted for aid delivery would be needed. Since such research, to the best knowledge of the author does not exist, it cannot with great certainty be claimed which type of organisation would have greater chances of accomplishing higher quality of management.

\section{Discussion and Need for Further Research Steps}

Academic research from the field of public administration has to date focused in large part on the question whether public organisations are different from private ones and how public management differs from private management. Furthermore, significant efforts were undertaken to examine how these organisational and managerial characteristics actually influence organisational output, efficiency and overall performance. 
The author has combined these findings from the public administration field with project management research focusing particularly on the development aid industry. The following conclusions can be made:

1. Due to very specific circumstances in which development aid takes place, as well as due to its soft results that are not as easy to measure, project management knowledge has to be attentively applied, taking industry-specific characteristics under careful consideration.

2. The influence of public-private differences on project management processes can be considered as relevant in this industry only in the following cases:

a. Public-private differences are proven and they are being continuously confirmed by subsequent results;

b. There are no serious indications that these differences could have different effects in the development aid industry;

c. Implications stemming from the attested differences affect one of the dimensions that have proven to be one of the success factors of development aid projects, such as the stakeholder management system, the information management system, the knowledge management system, or the team-leader.

This article has provided some initial considerations and possible explanations about the achievements of public and private implementing organisations in foreign aid delivery. The initial findings seem to slightly favour private companies over public ones and it could potentially lead to the conclusion that private companies are more likely to achieve better project management practices in development aid. Therefore, outsourcing the implementation of development aid projects could have overall positive effects on the impact of aid. The research deliberately omits other effects that contracting out and inclusion of private actors in development aid may have, such as the loss of accountability by the government, profit-maximising behaviour of for-profit actors, agenda setting by private actors etc... The author acknowledges the importance of these effects in development aid, encourages research which would deeply examine them, but they remain outside of the research focus. 
The assumptions about the positive effects of outsourcing would be in line with the practice of a great deal of donor countries, but not of all of them. For those agencies which do not outsource project implementation, this should show that if they would do so, for-profit companies would be able to achieve better quality of project management in the field than their staff is currently achieving. It could also have positive consequences on overall aid effectiveness as project management is one of the crucial components of overall project performance.

Nevertheless, in order to reach the final plausible conclusions, the following needs to be done:

- Incentives within organisations delivering foreign aid need to be deeply examined and their consequences thoroughly analysed. One such attempt has already been made by Andersson et al. (2005), on the example of Sida, but analyses comparing the two types of aid delivery have not yet been conducted;

- Contracts between donors and public agencies or donors and private companies delivering aid should be rigorously examined;

- Effects of contracting out and competition should be examined as they might have even greater importance than sectoral differences;

- In the end, a large-N empirical study measuring and qualitatively evaluating project management practices within both public and private implementers need to be conducted, which would then finally confirm or reject the findings.

Regardless of whether the findings would discover better management practices within public or private implementers, the final conclusions would imply the need for certain changes in the development aid industry. If private for-profit firms are able to achieve better quality of management practices when delivering development aid projects, this should be a wake-up call for Germany, Austria, Switzerland and other countries which are still using their own international cooperation agencies to deliver aid projects in partner countries. However, if it turns out that public agencies are actually doing a better job managing development aid projects, it would be a clear sign for most of bilateral development agencies, which are outsourcing aid delivery, that contracting out implementation of 
(2) development aid consequently did not achieve better management as initially assumed (Hart 1983).

This article is only the first step of an ongoing research and the additional ones are yet to follow. This entire research-project is motivated by the wish to provide policy findings for the field of development aid, so that, as a result, developing countries receive more effective and more sustainable aid in the future. 


\section{Bibliography}

Andersson, K., Auer, M., 2005. Incentives for Contractors in Aid-Supported Activities. In C. Gibson et al., eds. The Samaritan's Dilemma: The Political Economy of Development Aid. Oxford: Oxford University Press.

Ayittey, G. B. N., 2005. Africa Unchained: The Blueprint for Africa's Future. London: Palgrave-MacMillan.

Baarspul, H., Wilderom, C., 2011. Do Employees Behave Differently In Public- vs Private-Sector Organizations. Public Management Review, 13(7): 967-1003.

Baland, J. M., Moene, K. O., Robinson, J. A., 2010. Governance and Development. Handbook of development economics 5: 4597-656.

Baldwin, J. N., 1990. Perceptions of Public versus Private Sector Personnel and Informal Red Tape: Their Impact on Motivation. The American Review of Public Administration, 20(1): 7-28. Available at: http://arp. sagepub.com/cgi/doi/10.1177/027507409002000102 [accessed 22 September 2014].

Belassi, W., Tukel, O. I., 1996. A New Framework for Determining Critical Success/Failure Factors in Projects. International Journal of Project Management, 14(3): 141-151.

Berrios, R., 2000. Contracting for Development: The Role of For-Profit Contractors in U.S. Foreign Development Assistance. Westend: Praeger Publishers.

Bester, A., 2012. Results-Based Management in the United Nations Development System : Progress and Challenges. United Nations.

Bloom, N., Genakos, C., Sadun, R., Van Reen, J., 2011. Management Practices Across Firms and Countries. Academy of Management Perspectives, 26(1): 12-33.

Blunt, J. P., 1992. Managing Organisations in Africa. Berlin: Walter de Gruyter. 
Box, R. C., 1999. Running Government Like a Business: Implications for Public Administration Theory and Research. American Review of Public Administration, 29(1): 19-43.

Boyne, A. G., 1998. Public Choice Theory and Local Government: A Comparative Analysis of the UK and USA. London: Macmillan.

Boyne, A. G., 2002. Public and Private Management: What's the Difference? Journal of Management Studies, 39(1).

Bozeman, B., 1987. All Organizations Are Public: Bridging Public and Private Organizational Theories. San Francisco: Jossey-Bass.

Bozeman, B., Kingsley, G., 1998. Risk Culture in Public and Private Organizations. Public Administration Review, 58(2): 109-118.

Bozeman, B., Reed, P., Scott, P., 1992. Red Tape and Task Delays in Public and Private Organizations. Administration and Society, 24(3): 290322.

Bozeman, B., Scott, P., 1996. Bureaucratic Red Tape and Formalization: Untangling Conceptual Knots. American Review of Public Administration, 26(1): 1-17.

Bretschneider, S., 1990. Management information systems in public and private organizations: An empirical test. Public Administration Review, 50(5): 536-545.

Britton, B., 1998. The Learning NGO. Intrac Occasional Paper Series 17.

Buchanan, B., 1975. Red Tape and the Service Ethic: Some Unexpected Differences Between Public and Private Managers. Administration and Society, 6(4): 423-44.

Burnside, C., Dollar, D., 2000. Aid, policies, and growth. American Economic Review, 90(4): 847-68.

Carden, L., Egan, T., 2008. Does our Literature Support Sectors Newer to Project Management? The Search for Quality Publications Relevant to Nontraditional Industries. International Journal of Project Management, 39(3): 6-28.

Carroll, B. W., Garkut, D. E., 1996. Is There Empirical Evidence of a Trend Towards Managerialism? A Longitudinal Study of Six Countries. 
Canadian Public Administration, 39(4): 535-53.

Clarkson, K., 1972. Some Implications of Property Rights in Hospital Management. Journal of Law and Economics, 15: 363-84.

Cooke-Davies, T., 2002. The 'Real' Success Factors on Projects. International Journal of Project Management, 20: 185-190. Available at: http:// www.elsevier.com/locate/ijproman.

Crawford, L., 2000. Profiling the Competent Project Manager. In PMI Research Conference, Paris. pp. 3-15.

Crawford, P., Bryce, P., 2003. Project Monitoring and Evaluation: A Method for Enhancing the Efficiency and Effectiveness of Aid Project Implementation. International Journal of Project Management, 21.

Deininger, K., Squire, L., Basu, S., 1998. Does Economic Analysis Improve the Quality of Foreign Assistance? World Bank Economic Review, 12(3): 385-418.

Domberger, S., Jensen, P., 1997. Contracting out by the public sector: Theory, Evidence, Prospects. Oxford Review of Economic Policy, 13(4): 67-78.

Dwivedi, O. P., 2002. From Development Administration to Development Management. In Kirkpatric, C., Clarke, R., Polidano, C., eds. Handbook on DevelopmentPolicy and Management. Cheltenham, pp. 235-246.

Easterly, W., 2003. Can Foreign Aid Buy Growth. The Journal of Economic Perspectives, 17(3): 23-48.

Easterly, W., 2002. The Cartel of Good Intentions: The problem of Bureaucracy in Foreign Aid. Journal of Policy Reform, 5(4): 223-50.

Eđvarđsson, I. R., Sigurđardóttir, Á. L., 2010. Decision Making in Organisations: A Comparison between the Private and Public Sector. Icelandic Review of Politics and Administration, 6(2): 253-275.

Emmert, M., Crow, M., 1988. Public, Private and Hybrid Organizations An Empirical Examination of the Role of Publicness. Administration and Society, 20(2): 216-44.

Farnham, D., Horton, S., 1996. Managing Public and Private Organizations. 
In Farnham, D., Horton, S., eds. Managing The New Public Services. London: Macmillan, pp. 25-48.

Flint, M., 2003. Easier Said than Done. Herefordshire: DFID.

Fottler, M., 1981. Is management really generic? Academy of Management Review, 6: 1-12.

Gaddis, P. O., 1959. The Project Manager. Harvard Business Review, 37(3): 89-97.

Gibson, C. et al., 2005. The Samaritan's Dilemma: The Political Economy of Development Aid. Oxford: Oxford University Press.

Greener, I., 2013. Public Management, 2nd ed. London: Palgrave Macmillan.

Hart, O. D., 1983. The Market Mechanism as an Incentives Scheme. The Bell Journal of Economics, 14(2): 366-382.

High Level Forum, 2005. Paris Declaration on Aid Effectivness. Paris.

Holdaway, E. et al., 1975. Dimensions of Organizations in Complex Societies. Administrative Science Quarterly, 20(1): 37-58.

Hood, C., 1991. A Public Management for all Seasons? Public Administration, 69: 3-19.

Huysentruyt, M., 2011. Development Aid by Contract: Outsourcing and Contractor Identity. Available at: http://personal.Ise.ac.uk/ huysentr/Development Aid by Contract (Full).pdf

Hvidman, U., Andersen, S. C., 2013. Impact of Performance Management in Public and Private Organizations. Journal of Public Administration Research and Theory, 24(1): 35-58. Available at: http://jpart. oxfordjournals.org/cgi/doi/10.1093/jopart/mut019 [accessed 29 July 2014].

Ika, L. A., Diallo, A., Thuillier, D., 2012. Critical Success Factors for World Bank Projects: An Empirical Investigation. International Journal of Project Management, 30(1): 105-116. Available at: http:// linkinghub.elsevier.com/retrieve/pii/S026378631 1000469 [accessed 22 July 2014].

Ika, L. A., Diallo, A., Thuillier, D., 2010. Project Management in the 
International Development Industry: The Project Coordinator's Perspective. International Journal of Managing Projects in Business, 3(1): 61-93. Available at: http://www.emeraldinsight. com/10.1108/17538371011014035 [accessed July 14, 2014].

Ireland, M., Allister, M. G., Saltmare, D., 2003. Challenges for Donor Agency Country-Level Performance Assessment: A Review. Public Administration and Development, 23(5): 419-431.

Kapucu, N., 2007. New Public Management: Theory, Ideology, and Practice. In Farazmand, A., Pinkowski, J., eds. Handbook of Globalization, Governance, and Public Administration. Boca Raton: Taylor \& Francis Group, LLC, pp. 889-902.

Kerzner, H., 1998. Project Management: A System Approach to Planning, Scheduling and Controlling. New York: Van Nostrand Reinhold.

Khang, D. B., Moe, T. L., 2008. Success Criteria and Factors for International Development Projects: A Life Cycle Based Framework. Project Management Journal, 39(1): 72-84.

Kharas, N., 2011. Measuring Aid Effectiveness Effectively: A Quality of Official Development Assistance Index. Brookings Institution, Opinion. Available at: http://www.brookings.edu/research/ opinions/201 1/07/26-aid-effectiveness-kharas.

Kilby, C., 2000. Supervision and Performance - The Case of World Bank Projects. Journal of Development Economics, 62: 233-59.

Knutsen, C. H., 2009. The African Growth Tragedy Revisited: Strong States, Weak Rulers, Oslo.

Lachman, R., 1985. Public and Private Sector Differences: CEOs' Perceptions of Their Role Environments. Academy of Management Journal, 28(3): 671-80.

Lan, Z., Rainey, H., 1992. Goals, rules and effectiveness in public, private and hybrid organizations: more evidence on frequent assertions about differences. Journal of Public Administration Research and Theory, 2(1): 5-28.

Lau, A. W., Newman, A. R., Broedling, L. A., 1980. The Nature of Managerial Work in the Public Sector. Public Administration Review, 40(5): 513-520. 
Manning, N., 2002. The New Public Management in Developing Countries. In Kirkpatric, C., Clarke, R., Polidano, C., eds. Handbook on Development Policy and Management. Cheltenham: Edward Elgar, pp. 303-314.

Meier, K. J., O'Toole, L. J., 201 1. Comparing Public and Private Management: Theoretical Expectations. Journal of Public Administration Research and Theory, 21 (3): 283-299. Available at: http://jpart.oxfordjournals. org/cgi/doi/10.1093/jopart/mur027 [accessed 11 July 2014].

Meredith, M., 2006. The State of Africa. A History of Fifty Years of Independence, New York: The Free Press.

Miller, D., 2011 . Sachs, Easterly and the Banality of the Aid Effectiveness Debate: Time to Move On. Mapping Politics, 3: 72-86.

Mosley, P., 1985. The Political Economy of Foreign Aid: A Model of the Market for a Public Good. Economic Development and Cultural Change, 33(2): 373-93.

Murray, M. A., 1975. Comparing Public and Private Management: Exploratory Essay. Public Administration Review, 35(4): 364-371.

Nicholson-Crotty, S., O'Toole, L. J., 2004. Testing a Model of Public Management and Organizational Performance: The Case of Law Enforcement Agencies. Administration Research and Theory, 14(1): 1-18.

Nutt, P. C., Backoff, R. W., 1993. Organizational Publicness and Its Implications for Strategic Management. Journal of Public Administration Research and Theory, 3(2): 209-31.

O'Toole, L. J. J., Meier, J. K., 2003. Public Management and Educational Performance: The Impact of Managerial Networking. Public Administration Review, 63(6): 689-99.

O'Toole, L. J. J., Meier, J. K., 2004. Desperately Seeking Selznick: Cooptation and the Dark Side of Public Management in Networks. Public Administration Review, 64(6): 681-93.

Ortiz, E. F. et al., 2004. Implementation of Results-Based Management in the United Nations Organizations Part I Series on Managing for Results. Geneva. 
Pandey, S. K., Coursey, D. H., Moynihan, D. P., 2007. Organizational Effectiveness and Bureaucratic Red Tape: A Multimethod Study. Public Performance \& Management Review, 30(3): 398-425.

Pandey, S. K., Moynihan, D., 2006. Bureaucratic Red Tape and Organizational Performance: Testing the Moderating Role of Culture and Political Support. In Boyne, G. A. et al., eds. Public Service Performance Perspectives on Measurement and Management. Cambridge: Cambridge University Press.

Perry, J. L., Rainey, H. G., 1988. The Public-Private Distinction in Organization Theory: A Critique and Research Strategy. The Academy of Management Review, 13(2): 182-201.

Pinto, J. K., Slevin, D. P., 1987. Critical Success Factors in Effective Project Implementation. In Cleland, I. D., King, R. W., eds. Project Management Handbook. New York: Wiley\&Sons, pp. 479-512.

Project Management Institute, 2013. A Guide to the Project Management Body of Knowledge, Fifth Edit., Newtown Square: Project Management Institute.

Rainey, H. G., 1983. Public Agencies and Private Firms: Incentive Structures, Goals, and Individual Roles. Administration and Society, 15(2): 20742.

Rainey, H. G., 1989. Public Management: Recent Research on the Political Context and Managerial Roles, Structures, and Behaviors. Journal of Management, June (15): 229-250.

Rainey, H. G., 2009. Understanding and Managing Public Organizations, San Francisco: Jossey Bass.

Rainey, H. G., Backoff, R. W., Levine, C. H., 1976. Comparing public and private Organizations. Public Administration Review, 36(2): 233-244.

Ranson, S., Stewart, J., 1989. Citizenship and Government: The Challenge for Management in the Public Domain. Political Studies, 37(1): 5-24.

Roche, J. R. C., 1999. Impact Assessment for Development Agencies: Learning to Valve Change. Oxford: Oxfam.

Scott, P. G., Falcone, S., 1998. Comparing Public and Private Organizations: An Exploratory Analysis of Three Frameworks. The American Review 
of Public Administration, 28(2): 126-145. Available at: http://arp. sagepub.com/cgi/doi/10.1177/027507409802800202 [accessed September 25, 2014].

Sida. 1989. Rollutredningen. Stockholm: Sida.

Steinfort, P., 2010. Understanding the Antecedents of Project Management Best Practice - Lessons to be Learned for and from Aid/Relief Projects. Melbourne: RMIT University.

Steinfort, P., Walker, D. H. T., 2007. Proceedings of the PMOZ Achieving Excellence - 4th Annual Project Management Australia Conference. In Baccarini, D., ed. Critical Success Factors in Project Management Globally and How They May Be Applied to Aid Projects. Brisbane.

Tierney, M. J. et al., 201 1. More Dollars than Sense: Refining Our Knowledge of Development Finance Using AidData. World Development Journal, 39(11): 1891-1906.

UNESCO, 2008. Results-Based Management (RBM) Guiding Principles. Paris.

Vähämäki, J., Schmidt, M., Molander, J., 201 1. Result Based Management in Development Cooperation. Riksbankens Jubileumsfond, Stockholm.

Van de Walle, N., 2001. African Economies and the Politics of Permanent Crisis, 1979-1999, Cambridge: Cambridge University Press.

Wane, W., 2004. The Quality of Foreign Aid Country Selectivity or Donors Incentives? Development Research Group, The World Bank.

White, H., Woestman, L., 1994. The Quality of Aid, Measuring Trends in Donor Performance. Development and Change, 25(3): 527-54.

Williamson, O. E., 1999. Public and Private Bureaucracies: A Transaction Cost Economics Perspective. Journal of Law, Economics and Organization, 15(1): 306-42.

Wilson, J. Q., 1989. Bureaucracy What Do Government Agencies Do and Why They Do It? New York: Basic Books.

Woodward, J., 1958. Management and Technology, Cambridge: Cambridge University Press. 
Youker, R., 1999. Managing International Development. Project Management Journal, 30(2): 6-7.

Zimmerer, T., Yasin, M., 1998. A Leadership Profile of American Project Managers. Project Management Journal, 29(1): 31-38.

Dragana Simović (simovic.dragana@gmail.com) is a doctoral student at the University of Potsdam, the Department of Economics and Social Sciences. As an associate student she participates in the Research Training Group on "Wicked Problems, Contested Administrations: Knowledge, Coordination, Strategy" (WIPCAD). She graduated with a Bachelor's of Arts in Political Science (International Relations Department) from the University of Belgrade, and gained a Master of Arts degree in European and European Legal Studies from the Europa-Kolleg Hamburg, Hamburg University. She has three years of experience working on development aid projects in Serbia, financed by different donors. Her research interests focus primarily on development aid, its effectiveness, practices and consequences. Her current research project assesses the effects of contracting out and competition on the quality of project management in development aid, and is funded by the Konrad-Adenauer-Foundation. 